\title{
From Classroom to Online: Comparing the Effectiveness and Student Academic Performance of Classroom Learning and Online Learning
}

\author{
Bernard Fentim Darkwa1 (1), Samuel Antwi ${ }^{2}$ \\ ${ }^{1}$ Department of Business and Social Sciences Education, University of Cape Coast, Cape Coast, Ghana \\ ${ }^{2}$ School of Management and E-Business, Zhejiang Gongshang University, Hangzhou, China \\ Email: bernard.darkwa@ucc.edu.gh,samantwi88@outlook.com
}

How to cite this paper: Darkwa, B.F. and Antwi, S. (2021) From Classroom to Online: Comparing the Effectiveness and Student Academic Performance of Classroom Learning and Online Learning. Open Access Library Journal, 8: e7597.

https://doi.org/10.4236/oalib.1107597

Received: May 30, 2021

Accepted: June 28, 2021

Published: July 1, 2021

Copyright $\odot 2021$ by author(s) and Open Access Library Inc.

This work is licensed under the Creative Commons Attribution International License (CC BY 4.0).

http://creativecommons.org/licenses/by/4.0/

\begin{abstract}
The COVID-19 pandemic temporarily shifted the teaching and learning mode in most tertiary institutions in Ghana from the classroom to online. Accordingly, this present study aimed to compare classroom learning effectiveness during the coronavirus pandemic to the effectiveness before the coronavirus pandemic at the University of Cape Coast. The performance of students in both teaching and learning modes was also compared. This study was a case study research, and both primary and secondary data were employed. The effectiveness was measured using course content, pedagogical approaches, interactivity and assessment, feedback and evaluation. Data on effectiveness was collected using a questionnaire, and students' assessment was used to measure their performance. The data were analyzed using a paired-sample t-test embedded in Statistical Package for Social Sciences version 26. The results show that classroom learning was more effective than online learning. Additionally, the students exhibited good academic performance in classroom learning than online learning, although the difference was not statistically significant. The contribution of the findings is discussed.
\end{abstract}

\section{Subject Areas \\ Curriculum Development, E-Learning and Knowledge Management, Educational Technology, Higher Education}

\section{Keywords}

Effectiveness, Online Learning, Classroom Learning, Students Performance and COVID-19 


\section{Introduction}

In the later part of 2019, a novel coronavirus or COVID-19 was discovered in a seafood market in Wuhan [1]. After clinical trial analysis revealed that the virus could spread among individuals via close contact [2] [3], the World Health Organization in March 2020 declared the coronavirus as a pandemic [4] after assessment of the spread and severity of the virus. The COVID-19 made everything from world economies to social rituals devastated [5], as most countries had to institute a lockdown to contain the virus's spread. In Ghana, the first coronavirus case was recorded on March 10, 2020 [6]. The government subsequently instituted a partial lockdown in some cities, the Greater Accra Metropolitan Area and the Greater Kumasi Area, on March 30 to prevent the virus's spread [7] [8]. Even before the partial lockdown imposition, all educational institutions, including the various universities across the country, were temporally shut down in mid-March [9]. This was because it was quite not the best idea for students to be in the regular classroom amid the daily increase in coronavirus cases. To maintain social distancing is of paramount importance. Subsequently, some tertiary institutions in the country adopted the online learning or e-learning approach.

Thus, the coronavirus pandemic compelled schools to adopt digital academic experience as a new normal in the teaching and learning process [10]. The International Labor Organization (ILO) estimated about 195 million job losses in 2020 [11]. Even before that, [12] projected that about 264 million children and adolescents were not in school, and the pandemic has made the situation worst. [13] posited that the COVID-19 spread had forced various educational institutions to shift their teaching mode and learn from the traditional classroom to online. Technology has revolutionized the teaching and learning process in recent times. While teachers couldn't deliver instruction via the internet some years ago, the case is very different in recent years. The internet, computers, mobile phones, and other electronic gadgets have made the practice common. Online learning emerged as a safe and viable option for education continuity as the COVID-19 pandemic emerged, and a lot of institutions and economies had to shut down temporally.

Even before the coronavirus pandemic, [14] reported that online learning has emerged as a preferred method to access higher education, especially with the introduction of new technologies such as Web 2.0 and social media platforms. This form of learning has gained more popularity in advanced and developing countries such as China, Japan, Korea, the UK, the US, France, Germany, and some developing countries due to the Covid-19 pandemic. This finding conforms with [15]. To the researcher, China, United States of America, India, the United Kingdom, South Korea, and Côte d'Ivoire have been known to invest most in online learning. In Ghana, even before the pandemic, some tertiary institutions, including the University of Cape Coast employed online teaching and learning in some of the courses that the student reads. There have been several arguments 
on e-learning. Some of them are accessibility, affordability, pedagogy, assessment and evaluation, and institutional support.

This study aimed at comparing the effectiveness of classroom learning and online learning in the 2019/2020 academic year. The student academic performance in the two teaching modes for the 2019/2020 was also compared. The University of Cape Coast shifted part of their mode of teaching mode in the second semester of the 2019/2020 academic year from traditional classroom learning to online, following the closure of all schools by the Ghana government due to the spike in coronavirus infection. Consequently, most of the remaining weeks in the second semester of 2019/2020 were done online. The teaching and learning mode for the first semester of 2019/2020 was offline or traditional classroom learning because it was a pre-coronavirus era. The University of Cape Coast is one of the top-class universities in Ghana and Africa. The University was established in 1962 to train teachers for Ghana's education sector. However, the university has expanded its facilities to run diversified programs. The remainder of the research is as follows. The next section presents a literature review on classroom learning and online learning in addition to the research hypothesis. This is followed by the research methods and then continued with the data analysis. We then present the discussion of findings, and the contributions of the study are then presented. The study ends by presenting the limitations and future outlook.

\section{Literature Review}

\subsection{Online Learning and Classroom Learning}

Online learning has become one of the talking points in the 21st century. Online learning is the delivery of instruction via digital resources. This kind of learning is delivered through the use of electronic devices. Distance education, computerized electronic learning, and internet learning are other names used to describe online learning. The introduction of online learning means the students can now access their learning materials online and anytime. Emergence of technology has provided the avenue for education to be readily accessible at all levels over the past two decades.

According to [16], the early stage of distance or online education required usage of access to print materials that were emailed or sent to students and/or teachers. However, [17] reported that the development of e-learning management systems and web resources, as a result of technological advancement, transformed online education by boosting the pace at which information can be disseminated and digested. In recent online learning trends, videos and live broadcasting plays an important role. This is in line with [18], who posited that video is a more preferred means to online learning than documents, making learning more interactive and engaging.

As such, there is always a teacher who communicates or interacts with students in online learning, grades their participation in class activities, and also 
their assignments and tests. [19] anticipates that more visual technologies such as virtual reality (VR) and augmented reality (AR) are likely to find their way into the e-learning industry in the future. Over the past years, many researchers and institutions worldwide have researched the effectiveness of online learning.

Classroom learning is also known as traditional or offline learning. Learning is acquiring new knowledge, skills, behaviors, and preferences. It is an active process of engaging and manipulating experiences to build mental models of the world. Learners learn as they explore, observe and interact with the world around them. Consequently, it involves building on prior knowledge. According to [20], learning is a social activity that involves people who interact with the learning environment.

Initially, formal education requires students and teachers to meet at a physical place, usually referred to as a classroom. This is because the technologies that existed at the dawn of civilization or formal education could not make it possible for lessons to be conducted online. Consequently, most of the educational books written before the 21st century addressed classroom learning. Although online learning has gained some popularity in recent times, it is essential to know that classroom learning remains predominant, even in advanced countries like UK, China, the US, and others.

Classroom learning takes place in school, and there is a calendar or timetable and rules and regulations that stipulate how teaching and learning should be done. Classroom learning requires students to be active in learning environment. Students and teachers need to be physically present in the classroom for the teaching and learning to take place. Thus, the class teacher regulates and moderates information and knowledge flow. Classroom learning provides the platform for open exchange of ideas and face-to-face interaction between the students and the teachers which promotes socialization among the teachers and the students. Creating a conducive classroom environment for students learning should be the concern of every teacher to facilitate learning. Still, in the final analysis, the social and psychological activities and responses of each student determine what they learn.

\subsection{E-Learning at the University of Cape Coast during Schools' Closure amid Rises in COVID-19 Cases}

Towards the beginning of the second week of March 2020, as alerts sounded on the increasing number of coronavirus infection in Ghana, there were calls by various healthcare experts, educational experts, and the general public for the government to temporarily close down all schools to help curb the spread of the virus infection. Subsequently, the government announced an indefinite closure of all schools on March 16 [9]. Following the government order on all schools in the country to suspend their academic activities, the University of Cape Coast, among other educational institutions, was closed [21]. Globally, more schools were shut down to help contain the virus's spread. [22] report revealed that over 
1.2 billion children from 186 countries were out of the classroom due to the pandemic. Considering the alternative of no schooling, online learning became a necessity.

Consequently, some countries, especially the developed and developing countries, have adopted e-learning as a new way of teaching and learning. It should be noted that not all countries could fully implement online education because of finance and challenges. As such, [23] pointed out that technology, change, pace, finance, and competencies were a significant barrier to implementing digital transformation in education.

In Ghana, the University of Cape Coast, on April 1, 2020, announced the implementation of online learning following schools' closure on their official Facebook page. Accordingly, the lecturers were instructed to upload their teaching and learning resources for the second semester of the 2019/2020 academic year to the university online learning portal to facilitate online learning [24]. Additionally, the school adopted third-party e-learning platforms or video conferencing platforms such as Zoom, Google Classroom, and Recorded Lessons to facilitate the e-learning process. Amid the virus's continual spread globally and the need for students to study, some e-learning platforms offered their services for free [2]. [25] reported Edtech company, one of the world's most highly valued edtech companies, offered their platform, Byju's learning app, for free.

Some authors have questioned the effectiveness of online learning in the COVID-19 period. [26] separated online learning into two according to the initiated period. Thus, online learning before the global coronavirus pandemic and online learning in the global coronavirus pandemic. They see online learning in the period of COVID-19 pandemic as an emergency remote teaching because it contrasts with effective online learning. Effective online education is built on several research works, prototypes, theories, ethics, and assessment to concentrate on quality online course design, teaching, and learning. Online learning in the COVID-19 period lacks. In support of this, [27] asserted that online learning before the coronavirus pandemic is a byproduct of a well-planned design of instruction with an application of organized model for designing and developing teaching. Hence, the absence of these well-structured designs and development in online learning in the COVID-19 period [27] makes it an emergency remote teaching [26] [28] [29]. Nevertheless, online learning has been the efficient and the best way for teaching and learning. It is important to note that even though the University of Cape Coast implemented online education in the semester of $2019 / 2020$ academic year, no form of online assessments was conducted within the period. All the assessments were conducted through traditional means of writing examinations where students were asked to come to campus in batches to write the end-of-semester examination.

\subsection{Effectiveness of Classroom and Online Learning}

Online and classroom learning effectiveness was assessed using the course con- 
tent, pedagogical approaches, lesson interactivity and assessment, feedback, and evaluation. The variables mentioned above were used to measure the effectiveness of classroom learning because Directorate of Academic Planning and Quality Assurance (DAPQA) University of Cape Coast uses these variables for students' appraisal of courses every semester.

\subsubsection{Course Content}

Generally, content refers to facts, concepts, generalization, principles, and theories which students are expected to learn in school. It can be in the form of text or audio-visual and has the potential to educate, enlightens, or entertain people who go through it. According to [30], a subject matter's content includes organized knowledge, terms, information, facts, rules, principles, methods, concepts, decisions, phenomena, and related issues in the subject matter. The course content is an essential element of every school curriculum that needs much attention. The first category of [31] knowledge-based for teaching is content knowledge, which has to do with being knowledgeable about the subject matter. The teacher in a classroom is expected to have a broad and current understanding of the subject matter's major content areas. In the context of teaching, content is what teachers teach.

Every teacher's aim in the teaching and learning environment is to deliver a lesson to the learners' satisfaction. For students to fully understand a lesson, such a lesson's content should be presented clearly to facilitate students' understanding of the content. Also, the lesson should involve a series of activities to involve the students in the lesson through class participation. Activity-oriented lessons can enhance students' understanding of content through practice.

\subsubsection{Pedagogical Approaches}

Pedagogical approaches are the various strategies and skills teachers in the classroom used to translate the content of a lesson into a learnable bit for students' easy assimilation. There are different approaches teachers used in teaching a subjects in Ghana. [32] identified 1) "transmission of knowledge" (p. 51), 2) "student-centered teaching" (p. 51), and 3) question and answer approach" (p. 52) as three approaches used in teaching. Brainstorming method, individualized method, project method, and problem-solving method are also used by some teachers in the teaching and learning process.

A study by [33] also revealed that role-play, demonstration, and educational field experiences are also employed by teachers in teaching. Again, the study further indicated that expository teaching process, drills, teacher-led discussion, and case studies are other pedagogies employed in the teaching and learning environment. Notwithstanding the array of pedagogies available to teachers in the classroom, the dominant pedagogical stance remains one where students are largely regarded as "empty vessels," with little knowledge or experience [34].

\subsubsection{Interactivity}

Interactions between students, teachers, and students are essential in classroom 
learning. A student's ability to ask a question, share an opinion, or disagree with a point of view is a fundamental learning activity [35]. Through conversation, discourse, discussion and debate between students and between instructors and students' new concepts are clarified as well as old assumptions challenged. Interactions in the classroom provides platform for students to practice skills and also improve students' confidence and communicative skills. Both online learning and classroom learning requires students and teachers to interact in the teaching and learning process. Interaction in the classroom is often smooth with no or limited hindrance because of the instructor and the student's physical presence. In an e-learning class, the exchange takes the form of live video or pre-recorded video, electronic bulletin boards, mails, synchronous chat, and so forth.

The effectiveness of learning interaction in an online context has been widely argued in past literature. Some authors have argued that online interaction promotes student-centered learning and encourages participation more than classroom learning [36] [37]. To [38] the traditional classroom setting is more intimidating and exerts pressure on students; hence they may not participate appropriately in a lesson. Thus, students who find it challenging to participate in learning activities may feel isolated, affecting their performance. In light of this, [39] found that the more the interaction in an online learning platform, the higher the performance of the students.

\subsubsection{Assessment, Feedback, and Evaluation}

Assessment is an integral part of the teaching and learning process that challenges teachers to consider the variety of the assessment techniques that will meet the subject's learning needs [40]. Teachers use assessment to obtain information used to make decisions about students, curriculum, and educational policy. Different assessment procedures can assess students' knowledge in the classroom to determine whether the content taught has been understood.

Quality of student learning should not only be measured in terms of student learning achievement or success but also instruction's effectiveness in the classroom [41]. The development of an effective formative assessment system according to [41] is a necessary feature in teaching. Assessment must identify weaknesses and strengths in the student learning process through permanent feedback (p. 9). Student assessments track students' performance and ascertain whether the learning goals have been achieved. [42] noted that formative assessment enables teachers in making important daily instruction decisions. Through this kind of assessment, a teacher can monitor and interpret students' progress and give a constructive feedback to help improve the students' learning and the teaching methods. Formative assessment is well embraced by teachers at all levels of education in Ghana [43] [44]. The purpose of formative assessment in the classroom is to improve instruction. Thus, teachers and students use assessment information generated formatively to inform subsequent teaching and learning. 


\subsection{The Concept of Student Performance}

Student performance is a multi-dimensional construct made up of several constructs such as student grade, completion of a course or study program, building skills, and knowledge acquisition [16]. However, this research focuses on student's academic performance in an online learning context and classroom learning. The student's performance in both modes of learning plays a vital role in determining whether a lesson though or a course or a program that the students read was successful. Thus, the students' performance would help a teacher know whether the lesson thought was successful or not. Students' performance can be influenced by the course content learned, the teacher's pedagogical approaches, and the readiness to learn, among others. Student academic performance can serve as a basis for evaluating a teacher's competencies. Many researchers have found the difference in students' performance in online learning and classroom learning.

A report from the [45] on the comparison of online learning with offline learning found that, on average, students who studied in all or the majority of their courses in online perform better than students who took the same course in the more conventional, face-to-face or classroom format. Also, online learning was effective for a variety of learning contents and learner characteristics. Again, [46] found out that students who study via online performed better than those who study via offline. Additionally, a study conducted by [47] revealed that students in online and hybrid formats performed better than students in more traditional versions of comparable courses. [48] found significant differences in persistence between the two instructional modes, though no significant performance difference was noted as measured by the final grade. However, [49] found out that online learning and classroom learning are the same in terms of effectiveness.

\subsection{Research Questions}

Based on the literature reviewed, the study seeks to explore two research questions:

1) Are there differences in classroom learning effectiveness before the coronavirus and online learning during the coronavirus pandemic?

2) Are there differences in students' academic performance in classroom learning before the coronavirus and online learning during the coronavirus pandemic?

\section{Research Methods}

\subsection{Research Instrument}

The research was quantitative, and it employed both primary and secondary data for analysis. The secondary data comprised second-year Accounting Education students' final assessment (combination of class assessment and examination assessment) in Principles of Accounting I and II and Introduction to Business Management I and II for the 2019/2020 academic year. The primary data was 
collected using a questionnaire. The questionnaire was crafted to reflect the variables used for students' appraisal of courses by the Directorate of Academic Planning and Quality Assurance (DAPQA) at the University of Cape Coast in determining the effectiveness of classroom learning.

The questionnaire was closed-ended, and all items used a five-point Likert scale ranging from 1 (strongly disagree) to 5 (strongly agree). The questionnaire asked students to rate the course content's effectiveness, pedagogical approaches employed by the instructors, lesson interactivity, course assessment, feedback, and evaluation.

\subsection{Data Collection Procedure}

To solicit responses from the respondents, we employed a web-based survey method with Google Forms' help. The research is a case study, and as such, the participants were all second-Accounting Education students from the Department of Business and Social Sciences Education, University of Cape Coast. However, the participants participated in the study voluntarily. A message containing the study's purpose and the Uniform Resource Locator (URL) was sent to the participants' WhatsApp group by their lecturer. Additionally, we used secondary data (student test scores) to assess their performance.

\section{Data Analysis and Discussion}

The analytical instrument used was the Statistical Package for Social Sciences (SPSS). The respondent demographic data were analyzed using percentages and frequencies. Additionally, we assessed the measurement items' internal consistency using the Cronbach alpha. The correlation coefficients between the constructs were also examined. We employed the paired-samples t-test to find the differences in learning effectiveness and students' academic performances to address the research questions.

\subsection{Respondents Demographic Information}

The results from Table 1 revealed that most of the respondents who participated in the study were males $(67.6 \%)$, and the remaining were females $(32.4 \%)$. Regarding their age range, more than two-thirds of the respondents (80\%) were between 20 - 25 years, followed by 26 - 30 years (14.5\%) and then below 20 years $(4.8 \%)$ and lastly above 30 years (1\%). Concerning the respondents' access to electronic devices such as personal computers, mobile phones, tablets, iPad, and others of similar kinds, all the respondents $(100 \%)$ had access to an electronic device.

The results from Table 1 further showed that $37.9 \%$ of the respondents' monthly expenditure of internet data ranged from GHष 31 - 50, and the same percentage spent over GH\& 50 on internet data in a month. Additionally, $22.1 \%$ of the respondents spent an average of $\mathrm{GH} \$ 10-30$ on monthly internet data, whereas $2.1 \%$ spent less than $\mathrm{GH} \$ 10$ on internet data in a month. 
Table 1. Demographic information of respondent.

\begin{tabular}{cccc}
\hline Variable & Characteristics & Frequency & Percentage \\
\hline Gender & Male & 98 & 67.6 \\
& Female & 47 & 32.4 \\
\hline Age (in years) & Below 20 & 7 & 4.8 \\
& $20-25$ & 116 & 80 \\
& $26-30$ & 21 & 14.5 \\
\hline Access to Electronic Device & Ybove 30 & 1 & 0.7 \\
\hline & Less than 10 & 145 & 100 \\
\hline Monthly Expenditure on & $10-30$ & 3 & 2.1 \\
Internet Data (in GHष) & $31-50$ & 32 & 37.9 \\
& Above 50 & 55 & 37.9 \\
\hline
\end{tabular}

Source: Author's contribution with SPSS version 26.

\subsection{Validity and Reliability Assessment}

According to [50], one way to ensure that measurement error is kept to a minimum is to determine the measure's properties. Consequently, a reliability assessment was carried on the secondary data. Cronbach's alpha is one of the most used techniques for testing internal reliability, and the ideal Cronbach alpha threshold is considered over 0.70 [51]. As shown in Table 2, the Cronbach alpha values exceeded the threshold of 0.70 , highlighting the measurement items' high reliability. The validity of the measurement items was assessed using the factor loadings. The general rule is that the factor loadings should be greater than 0.70 [52]. Table 2 shows that all the factor loadings were above the threshold of 0.70 .

\subsection{Correlation Coefficient of Constructs}

Table 3 and Table 4 display the correlation coefficient between the constructs under study.

The results indicate that all the study variables are inter-correlated with each other. Again, it was found that all the variables are statistically significant and positively correlated to each other.

\subsection{Presentation and Discussion of Findings}

Table 5 and Table 6 present the research questions posed for the study. This was done using the Paired-Samples t-test embedded in the SPSS software. The pairedsamples t-test was appropriate as it enables the same subject to be observed twice, often with some intervention taking place between the measures. We calculated the overall means and standard deviations of students' effectiveness and performance of the two learning modes. 
Table 2. Validity and reliability of the measurement model.

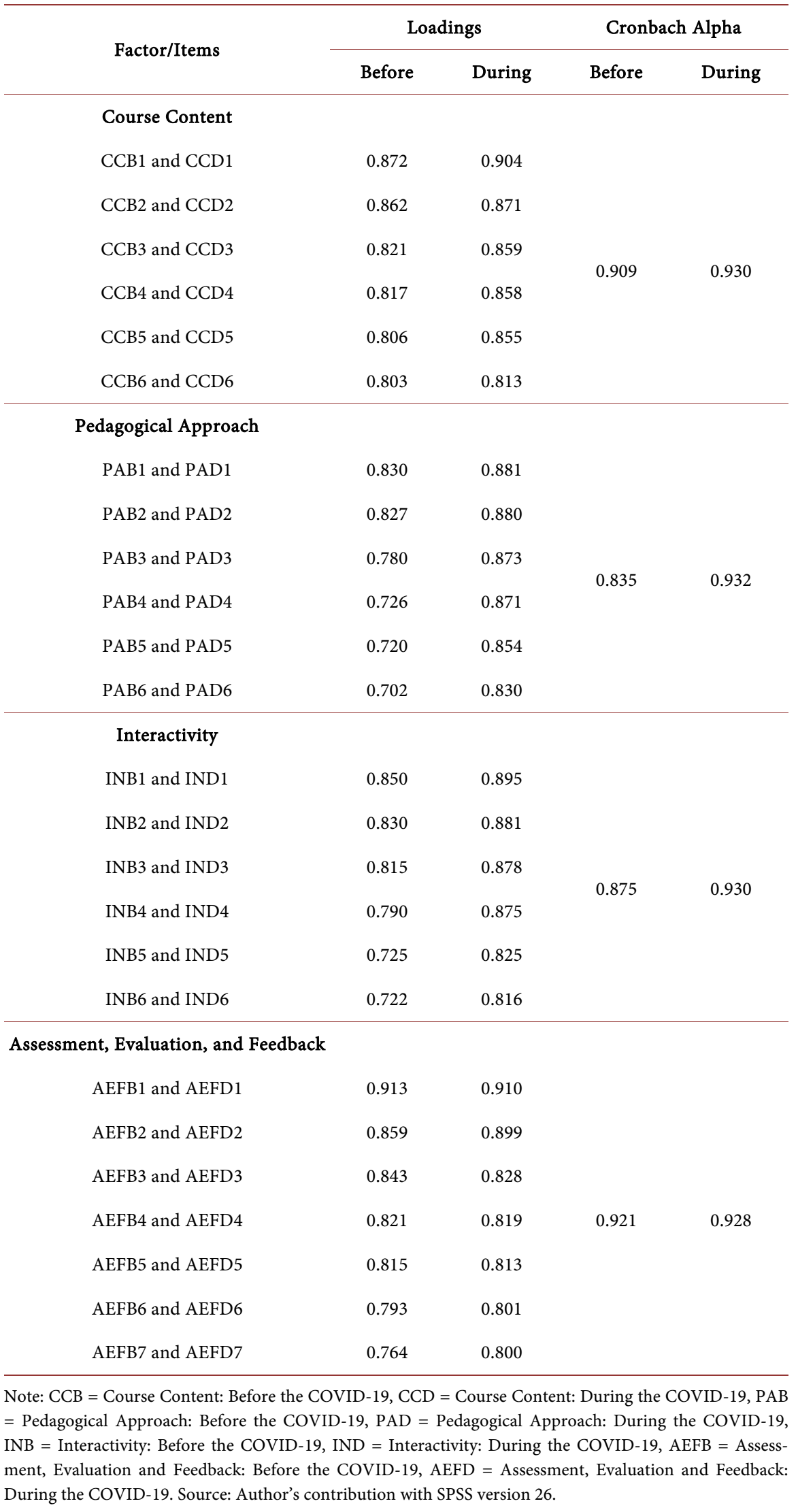


Table 3. Correlations coefficients of constructs (Before COVID-19).

\begin{tabular}{ccccc}
\hline Variable & CCB & PAB & INB & AEFB \\
\hline CCB & 1 & & & \\
PAB & $0.537^{* *}$ & 1 & & \\
INB & $0.513^{* *}$ & $0.688^{* *}$ & 1 & 1 \\
AEFB & $0.373^{* *}$ & $0.466^{* *}$ & $0.474^{* *}$ & 1 \\
\hline
\end{tabular}

Note: p-value $<0.01$, Source: Author's contribution with SPSS version 26.

Table 4. Correlations coefficients of constructs (During COVID-19).

\begin{tabular}{ccccc}
\hline Variable & CCD & PAD & IND & AEFD \\
\hline CCD & 1 & & & \\
PAD & $0.704^{* *}$ & 1 & & \\
IND & $0.615^{* *}$ & $0.836^{* *}$ & 1 & 1 \\
AEFD & $0.585^{* *}$ & $0.664^{* *}$ & $0.748^{* *}$ & 1 \\
\hline
\end{tabular}

Note: $\mathrm{p}$-value $<0.01$, Source: $=$ Author's contribution with SPSS version 26.

Table 5. Effectiveness and performance of students before and during COVID-19.

\begin{tabular}{ccccc}
\hline \multirow{2}{*}{ Constructs } & \multicolumn{2}{c}{ Before COVID-19 } & \multicolumn{2}{c}{ During COVID-19 } \\
\cline { 2 - 5 } & Mean & SD & Mean & SD \\
\hline Course Content & 4.303 & 0.643 & 3.133 & 0.940 \\
Pedagogical Approach & 4.171 & 0.550 & 3.240 & 0.969 \\
Interactivity & 4.293 & 0.591 & 3.062 & 1.058 \\
Assessment, Evaluation and Feedback & 4.183 & 0.676 & 3.324 & 1.004 \\
Performance & 68.286 & 10.147 & 68.145 & 8.835 \\
\hline
\end{tabular}

Source: Author's contribution with SPSS version 26.

Table 6. Mean difference in classroom learning before COVID-19 and online learning during COVID-19.

\begin{tabular}{|c|c|c|c|c|}
\hline Constructs & $\begin{array}{c}\text { Means } \\
\text { Differences }\end{array}$ & t-value & $\mathrm{df}$ & $\begin{array}{c}\text { Sig. } \\
\text { (two-tailed) }\end{array}$ \\
\hline $\begin{array}{l}\text { Course Content before COVID-19 vs } \\
\text { Course Content during COVID-19 }\end{array}$ & 1.170 & 13.124 & 144 & $0.000^{\star *}$ \\
\hline $\begin{array}{l}\text { Pedagogical Approach before COVID-19 vs } \\
\text { Pedagogical Approach during COVID-19 }\end{array}$ & 0.931 & 10.070 & 144 & $0.000^{* *}$ \\
\hline $\begin{array}{l}\text { Interactivity before COVID-19 vs } \\
\text { Interactivity during COVID-19 }\end{array}$ & 1.231 & 12.466 & 144 & $0.000^{* *}$ \\
\hline $\begin{array}{c}\text { Assessment, Evaluation and Feedback before } \\
\text { COVID-19 vs Assessment, Evaluation and } \\
\text { Feedback during COVID-19 }\end{array}$ & 0.859 & 8.330 & 144 & $0.000^{\star *}$ \\
\hline $\begin{array}{l}\text { Student Performance before COVID-19 } \\
\text { Student Performance during COVID-19 }\end{array}$ & 0.141 & 0.236 & 144 & 0.814 \\
\hline
\end{tabular}

Note: ${ }^{* *}$-value $<0.01, \mathrm{df}=$ degree of freedom, Source: Author's contribution with SPSS version 26. 
Additionally, the differences in means of classroom learning and online learning and their significant level are presented in Table 6.

According to Table 5, course content before the coronavirus (classroom learning) had the highest mean $(\mathrm{M}=4.303, \mathrm{SD}=0.643)$ as compared to the course content during the coronavirus where the learning was shifted to online learning $(\mathrm{M}=3.133, \mathrm{SD}=0.940)$. This resulted in a mean difference of 1.170 points (see Table 6). The t-value was 13.124 with 144 degrees of freedom. The t-value was statistically significant at the 0.05 alpha ( $\mathrm{p}$-value $=0.000$ ). In other words, course content before the coronavirus (classroom learning) was significantly different from and in fact, significantly higher than during the coronavirus (online learning). The finding implies classroom learning was more effective than online learning with respect to the lesson content. Thus, the course content was well understood by students in classroom learning than online learning. A possible explanation for this is that the classroom mode of learning is predominant in all Ghana cycles. Students have experience classroom right from their primary education and are convenient.

The results from Table 5 further revealed that course content before the coronavirus (classroom learning) had the highest mean $(\mathrm{M}=4.171, \mathrm{SD}=0.550)$ as compared to the course content during the coronavirus where the learning was shifted to online learning $(\mathrm{M}=3.240, \mathrm{SD}=0.969)$. Additional results in Table 6 reveal a mean difference of 0.931 points. The mean difference was found to be statistically significant $(\mathrm{t}$-value $=10.070, \mathrm{df}=144, \mathrm{p}$-value $=0.000)$. The results imply that in terms of effectiveness, the teachers' pedagogical approaches during classroom learning were more effective than online learning.

In terms of lesson interactivity, the results from Table 5 showed that interactivity before the coronavirus was higher $(\mathrm{M}=4.293, \mathrm{SD}=0.591)$ than the interactivity during the coronavirus pandemic $(\mathrm{M}=3.062, \mathrm{SD}=1.058)$. The mean difference, 1.231 points, was found to be statistically significant ( $\mathrm{t}$-value $=12.466$, $\mathrm{df}=144$, $\mathrm{p}$-value $=0.000$ ). Thus, lesson interactivity before the COVID-19 was significantly higher than during the coronavirus epidemic, where the school had to resort to online learning. The finding implies lesson interactivity is more effective in classroom learning than online learning.

In the same fashion, assessment, evaluation, and feedback before the coronavirus had the highest mean $(\mathrm{M}=4.183, \mathrm{SD}=0.676)$ compared to during the coronavirus pandemic $(\mathrm{M}=3.324, \mathrm{SD}=1.004)$. Consequently, a mean difference of 0.859 was recording. The mean difference between the two constructs was statistically significant $(\mathrm{t}$-value $=8.330, \mathrm{df}=144$, $\mathrm{p}$-value $=0.000)$, indicating assessment, evaluation and feedback before the coronavirus epidemic was more effective than during the coronavirus epidemic.

The student's academic performance was assessed using their assessment (both class score and examination score) in Principles of Accounting and Introduction to Business Management. The use of these two courses was appropriate because the students read the course in both first semester (before the coronavirus) and the second semester (during the coronavirus). The results from Table 5 
revealed the students' average score before the coronavirus $(\mathrm{M}=68.286, \mathrm{SD}=$ 10.147) was higher than their score during the coronavirus $(\mathrm{M}=68.145, \mathrm{SD}=$ 8.835 ). This resulted in a mean difference of 0.141 . The mean difference between student academic performance in classroom learning and online learning was not statistically significant $(\mathrm{t}$-value $=0.236, \mathrm{df}=144, \mathrm{p}$-value $=0.814$ ). Thus, the students exhibited good academic performance in classroom learning compared to online learning, although the difference was not statistically significant. Our findings contrast an earlier research of [46], that students who learn via online perform better than those who learn in the classroom.

\section{Study Contribution}

The present study makes some contributions in the field of academia and practice. Our research offers a significant contribution to education technology literature by examining the differences in classroom learning effectiveness and online learning. This study is one of the pioneer research studies investigating the differences in efficacy and performance of classroom learning and online learning from the Ghanaian context to the best of our knowledge and available literature. The study will help educational stakeholders in Ghana, such as the Ministry of Education, university policymakers, and other relevant stakeholders on online education in Ghana. Historically, Ghana's teaching mode has always been the traditional classroom system at all levels of education. The findings reveal that classroom learning was more effective than online learning, and students perform better in classroom learning than online learning, although the difference was not statistically significant. It is not surprising as students spent their entire years in school learning mainly in the classroom. Thus, both teachers and students are not familiar with online learning mode. Again, the research lends itself to critical analysis and conscious uptake and establishment of online learning by the relevant education stakeholders, especially in this digital era and the fact that the upcoming generation comprises millennials/Generation Y (Born between 1981 and 1996). Generation Z (born between 1996 and 2010) are more tech-savvy and would eventually shift competition in education to favor online educators.

Our study further opens up a divergent area of concern in marketing education and education-related resources to either an online-only option or a blended learning approach. A gradual process using the mixed approach to education from early childhood ages of education is a worthy suggestion to consider by education stakeholders with or without Covid-19 or any lurking pandemic in the future. The present study reveals that teachers can teach well in the classroom than online. Thus, teachers' pedagogical content knowledge in classroom learning is more effective than online learning. Although technology and the internet can replace teachers with content knowledge and provide extensive learning resources, teachers are still needed to assist students with a more profound cognitive process level. Therefore, university lecturers need to be given in-service training on education technology. Teacher training programs should also focus 
on integrating technology with pedagogy and content to bring forth more desirable effects in upcoming teachers or lecturers.

\section{Limitation and Future Outlook}

This present study, like many other researches, has some limitations. Firstly, several constructs can be used to access learning effectiveness; however, this present study was limited to course content, pedagogical approaches employed by the teacher, lesson interactivity and assessment, evaluation, and feedback mechanisms employed. Again, the student's performance was assessed using students' assessment (class score and examination score) in only two courses: Principles of Accounting and Introduction to Business. Also, the study was limited to Ghana, and hence, the findings may not be applicable in other countries that adopted online learning during the coronavirus epidemic. Even in Ghana, the study was limited to level 200 Accounting students at the Department of Business and Social Sciences Education at the University of Cape Coast. We suggest that future studies compare many educational institutions to find out if the findings will remain the same in those institutions. Before the coronavirus pandemic, where the learning mode was shifted to online, the student had not experienced a full term or semester of online learning and might affect their responses. Again, the present study collected primary data from only students. Future research may draw analogies by collecting data from both students and teachers. It is important to note that even though the University of Cape Coast implemented online education in the semester of 2019/2020 academic year, no form of online assessments was conducted within the period. All the assessments were conducted through traditional means of writing examinations where students were asked to come to campus in batches to write the end-of-semester examination.

\section{Conclusion}

This present study investigated students' effectiveness and performance in classroom learning and online learning in the Ghanaian context. This present study is a case study research, and both primary data and secondary data were employed. Specifically, the effectiveness of teaching and learning was measured using a questionnaire, and the students' performance was assessed using their assessment. To answer the research questions posed for the study, we employed paired-sample t-test embedded in SPSS software to analyze both the primary and secondary data. The results show that the teaching and learning were more effective before the coronavirus than during the coronavirus. Similarly, the student's average performance before the coronavirus was found to be higher than their average score during the coronavirus. The study contributions and limitations were all presented.

\section{Conflicts of Interest}

The authors declare no conflicts of interest. 


\section{References}

[1] Huang, C., et al. (2020) Clinical Features of Patients Infected with 2019 Novel Coronavirus in Wuhan, China. The Lancet, 395, 497-506.

https://doi.org/10.1016/S0140-6736(20)30183-5

[2] Li, C. and Lalani, F. (2020) The COVID-19 Pandemic Has Changed Education Forever. This Is How.

https://www.weforum.org/agenda/2020/04/coronavirus-education-global-covid19-o nline-digital-learning

[3] Paules, C.I., Marston, H.D. and Fauci, A.S. (2020) Coronavirus Infections-More than Just the Common Cold. Journal of the American Medical Association, 323, 707708. https://doi.org/10.1001/jama.2020.0757

[4] WHO (2020) Coronavirus Disease (COVID-19) Pandemic. World Health Organization, Geneva. https://www.who.int/emergencies/diseases/novel-coronavirus-2019

[5] Schulten, K. (2020) Coronavirus Resources: Teaching, Learning and Thinking Critically. New York Times.

https://www.nytimes.com/2020/03/11/learning/coronavirus-resources-teaching-lear ning-and-thinking-critically.html

[6] Ministry of Health Ghana (2020) First Confirmed COVID-19 Cases in Ghana. https://www.ghanahealthservice.org/covid19/downloads/covid 19 first confirmed GH.pdf

[7] Eyewitness News (2020) Ghana Announces Lockdown in Two Key Regions. https://ewn.co.za/2020/03/28/ghana-announces-lockdown-in-two-key-regions

[8] Aljazeera News (2020) Ghanaians Welcome End of Three-Week Lockdown with Mixed Emotions. Coronavirus Pandemic News. Al Jazeera.

https://www.aljazeera.com/news/2020/4/20/ghanaians-welcome-end-of-three-weeklockdown-with-mixed-emotions

[9] BBC News (2020) Coronavirus-Virus: Ghana Schools Closed, Religious, Sports Activities Chop Ban to Fight Covid-19 Disease-BBC News Pidgin.

https://www.bbc.com/pidgin/tori-51904164

[10] Lederman, D. (2020) Will Shift to Remote Teaching Be Boon or Bane for Online Learning. Inside Higher Ed, 1-27.

https://www.insidehighered.com/digital-learning/article/2020/03/18/most-teachinggoing-remote-will-help-or-hurt-online-learning

[11] UNDP (2020) COVID-19 Pandemic Humanity Needs Leadership and Solidarity to Defeat the Coronavirus.

https://www.delog.org/events/details/covid-19-pandemic-humanity-needs-leadershi p-and-solidarity-to-defeat-the-coronavirus

[12] UNESCO (2017) Accountability in Education: Meeting Our Commitments; Global Education Monitoring Report, 2017/8-UNESCO Digital Library. https://unesdoc.unesco.org/ark:/48223/pf0000259338

[13] Martinez, J. (2020) Take This Pandemic Moment to Improve Education. EdSource. https://edsource.org/2020/take-this-pandemic-moment-to-improve-education/6335 $\underline{00}$

[14] Kennedy, K. and Archambault, L. (2012) Offering Preservice Teachers Field Experiences in K-12 Online Learning: A National Survey of Teacher Education Programs. Journal of Teacher Education, 63, 185-200. https://doi.org/10.1177/0022487111433651

[15] Dos Santos, C. (2019) What Are the Leading Countries in the eLearning Industry? 
https://www.elearningnews.it/en/e-learning-news-C-18/studies-C-26/what-are-the-1 eading-countries-in-the-elearning-industry-AR-510

[16] Hurlbut, A.R. (2018) Online vs. Traditional Learning in Teacher Education: A Comparison of Student Progress Comparison of Student Progress. American Journal of Distance Education, 32, 248-266. https://doi.org/10.1080/08923647.2018.1509265

[17] Finger, G., McGlasson, M. and Finger, P. (2007) Information Security and Ethics: Tools, and Applications Information Science Reference. Technol. Divers. High. Educ. New Challenges, Vol. I, 81-103.

[18] Kaltura (2019) Video and Learning at Work: The State of Video in the Enterprise 2019. https://corp.kaltura.com/resources/state-video-enterprise-2019/\#rad

[19] The Franklin Institute (2020) What's the Difference between AR, VR, and MR? https://www.fi.edu/difference-between-ar-vr-and-mr\#: :text=Augmentedreality(AR addsdigit-

al,thecameraonasmartphone.\&text=InaMixedReality(MR, worldanddigitalobjectsint eract

[20] Bransford, J., et al. (2007) Learning Theories and Education: Toward a Decade of Synergy.

[21] University of Cape Coast (2020) Closure of the University of Cape Coast. University of Cape Coast, Cape Coast.

https://www.ucc.edu.gh/press-release/closure-university-cape-coast-0

[22] UNESCO (2020) Education: From Disruption to Recovery. https://en.unesco.org/covid19/educationresponse

[23] Kopp, M., Gröblinger, O. and Adams, S. (2019) Five Common Assumptions That Prevent Digital Transformation at Higher Education Institutions. INTED2019 Proceedings, 13th International Technology, Education and Development Conference, Valencia, 11-13 March 2019, 1448-1457. https://doi.org/10.21125/inted.2019

[24] University of Cape Coast (2020) Engagement of Students Online and Uploading of Courses on Moodle Platform. https://www.facebook.com/175176769177840/posts/3814383078590506

[25] The Times of India (2020) Byju's Adds Free Live Classes for Students amidst COVID-19 Lockdown.

https://timesofindia.indiatimes.com/gadgets-news/byjus-adds-free-live-classes-for-s tudents-amidst-covid-19-lockdown/articleshow/74971274.cms

[26] Hodges, C., Moore, S., Lockee, B., Trust, T. and Bond, A. (2020) The Difference between Emergency Remote Teaching and Online Learning. Educational Review. https://er.educause.edu/articles/2020/3/the-difference-between-emergency-remote-t eaching-and-online-learning

[27] Branch, R.M. and Dousay, T.A. (2015) Survey of Instructional Design Models. 5th Edition, Association for Educational Communications and Technology, Bloomington.

[28] Bozkurt, A. and Sharma, R.C. (2020) Emergency Remote Teaching in a Time of Global Crisis Due to Coronavirus Pandemic. Asian Journal of Distance Education, 15, 16. http://asianjde.org/ojs/index.php/AsianJDE/article/download/447/297

[29] Vlachopoulos, D., Tejeiro, R. and Edwards, A. (2020) Indirect Feedback: A Dialoguing Approach to Assessment. Higher Learning Research Communications, 9, 6471. https://doi.org/10.18870/hlrc.v9i1.444

[30] Madadlou, G. and Gharaaini, K.R. (2014) A Review of Criteria for Content Selection in Primary Education Curriculum. Eurasia Proceedings of Educational and Social Sciences, Vol. 1, 112-116. https://dergipark.org.tr/en/pub/epess/issue/30314/332804 
[31] Shulman, L.S. (1986) Those Who Understand: Knowledge Growth in Teaching. Educational Research, 15, 4-14. https://doi.org/10.3102/0013189X015002004

[32] Akyeampong, K. (2003) Teacher Training in Ghana-Does It Count? Multi-Site Teacher Education Research Project. https://ageconsearch.umn.edu/record/12867/files/er03049b.pdf

[33] Ghana Education Service and Teacher Education Division (2004) Trends in Education and School Management in Ghana. Accra.

[34] Lewin, K.M. and Stuart, J.S. (2003) Researching Teacher Education: New Perspectives on Practice, Performance, and Policy.

https://ageconsearch.umn.edu/record/12882/files/er03049a.pdf

[35] Dhawan, S. (2020) Online Learning: A Panacea in the Time of COVID-19 Crisis. Journal of Educational Technology Systems, 49, 5-22. https://doi.org/10.1177/0047239520934018

[36] Karayan, S.S., Karayan, S.S. and Crowe, J.A. (1997) Student Perceptions of Electronic Discussion Groups. T.H.E. Journal, 24, 69-71.

https://www.learntechlib.org/p/82479

[37] Smith, D. and Hardaker, G. (2000) e-Learning Innovation through the Implementation of an Internet Supported Learning Environment on JSTOR. Educational Technology \& Society, 3, 422-432. http://www.jstor.org/stable/jeductechsoci.3.3.422

[38] Warschauer, M. (1997) Computer-Mediated Collaborative Learning: Theory and Practice. Modern Language Journal, 81, 470-481.

https://doi.org/10.1111/j.1540-4781.1997.tb05514.x

[39] Davies, J. and Graff, M. (2005) Performance in e-Learning: Online Participation and Student Grades. British Journal of Educational Technology, 36, 657-663. https://doi.org/10.1111/j.1467-8535.2005.00542.x

[40] Nolen, S.B. (2011) The Role of Educational Systems in the Link between Formative Assessment and Motivation. Theory into Practice, 50, 319-326. https://doi.org/10.1080/00405841.2011.607399

[41] Mateo, J. and Sangra, A. (2007) Designing Online Learning Assessment through Alternative Approaches: Facing the Concerns. European Journal of Open, Distance and E-Learning, 10, 42.

http://citeseerx.ist.psu.edu/viewdoc/download?doi=10.1.1.444.1529\&rep=rep1\&type $=$ pdf

[42] Jia, Y.M. (2004) English as a Second Language: Teacher's Perception and Use of Classroom-Based Reading Assessment. Texas A\&M University, College Station.

[43] Asare, K. (2015) Exploring the Kindergarten Teachers' Assessment Practices in Ghana. Developing Country Studies, 5, 110-128.

https://www.iiste.org/Journals/index.php/DCS/article/view/21796/21990

[44] Amoako, I. (2018) Formative Assessment Practices among Distance Education Tutors in Ghana. African Journal of Teacher Education, 7, 22-36. https://doi.org/10.21083/ajote.v7i3.4325

[45] U.S. Department of Education (2009) Evaluation of Evidence-Based Practices in Online Learning. https://eric.ed.gov/?id=ED505824

[46] Shachar, M. and Neumann, Y. (2010) Twenty Years of Research on the Academic Performance Differences between Traditional and Distance Learning: Summative Meta-Analysis and Trend. MERLOT Journal of Online Learning and Teaching, 6, 318-334. http://jolt.merlot.org/vol6no2/shachar 0610.pdf

[47] Wu, D.D. (2015) Online Learning in Postsecondary Education: A Review of the 
Empirical Literature. Ithaka, 1-45. https://doi.org/10.18665/sr.221027

[48] McLaren, C.H. (2004) A Comparison of Student Persistence and Performance in Online and Classroom Business Statistics Experiences. Decision Sciences Journal of Innovative Education, 2, 1-10. https://doi.org/10.1111/j.0011-7315.2004.00015.x

[49] Means, B., Toyama, Y., Murphy, R. and Baki, M. (2013) The Effectiveness of Online and Blended Learning: A Meta-Analysis of the Empirical Literature. Teachers College Record, 115, Article ID: 030303.

https://agronomy.unl.edu/online/documents/Effectiveness of online learning.pdf

[50] Field, A. (2005) Discovering Statistics Using SPSS. 2nd Edition, Sage Publications, London.

[51] Hair, J.F., Black, W.C., Babin, B.J., Anderson, R.E. and Tatham, R.L. (2010) Multivariate Data Analysis. 7th Edition, Pearson, New York.

[52] Hair, J.F., Ringle, C.M. and Sarstedt, M. (2011) PLS-SEM: Indeed a Silver Bullet. Journal of Marketing Theory and Practice, 19, 139-152.

https://doi.org/10.2753/MTP1069-6679190202 


\section{Research Survey}

The purpose of the study is to compare the effectiveness and performance of classroom learning before the COVID-19 and the online learning during the COVID19 era. You are therefore invited to participate in this survey. Any information provided for this study will be treated with utmost confidentiality and anonymity. This questionnaire is designed for academic purpose only.

\section{Section A}

\section{Background Information}

BI1. Gender
1) Male
2) Female

BI2. Age (in years):
1) Below 20
2) 20 - 25
3) $26-30$
4) Above 30

BI5. Do you have access to electronic device (examples; smartphones, tablets and personal computers) to access the internet
1) Yes
2) No

BI6. How much do you spent on internet data in a month (in GHథ)
1) Less than 10
2) 10 - 30
3) $31-50$
4) Above 50

\section{Section B}

Rate the extent to which the following statements in the matrix represented below reflects to you. Use a scale of 1 to $5(1=$ Strongly Disagree, $2=$ Disagree, $3=$ Uncertain, $4=$ Agree, 5 = Strongly Agree). How much do you agree with each statement about you as you generally are now, not as you wish to be in the future?

Tick as applicable.

\section{Course Content: Before the COVID-19}

CCB1: The content of the lesson was clear

CCB2: The content of the lesson was well understood

CCB3: The content of the lesson was well delivered

CCB4: The activities in the lesson helped me to understand the lesson better

CCB5: The examples given by the teacher enhanced my understanding of the lesson

CCB6: I was able to relate the concepts to real life application

\section{Course Content: During the COVID-19}

CCD1: The content of the lesson was clear

CCD2: The content of the lesson was well understood

CCD3: The content of the lesson was well delivered

CCD4: The activities in the lesson helped me to understand the lesson better

CCD5: The examples given by the teacher enhanced my understanding of the 
lesson

CCD6: I was able to relate the concepts to real life application

\section{Pedagogical Approach: Before the COVID-19}

PAB1: The lesson delivery was exceptional

PAB2: The delivery of the lesson was well supported by examples

PAB3: The teacher varied his/her teaching styles

PAB4: The teacher frequently uses various resources/materials during lesson delivery

PAB5: The teacher uses clear unambiguous statements to explain concepts in the lesson

PAB6. The organization of the lesson was appropriate, logical and clear

\section{Pedagogical Approach: During the COVID-19}

PAD1: The lesson delivery was exceptional

PAD2: The delivery of the lesson was well supported by examples

PAD3: The teacher varied his/her teaching styles

PAD4: The teacher frequently uses various resources/materials during lesson delivery

PAD5: The teacher used clear unambiguous statements to explain concepts in the lesson

PAD6. The organization of the lesson was appropriate, logical and clear

\section{Interactivity: Before the COVID-19}

INB1: The teacher gave adequate opportunity for us to involve and participate in the lesson

INB2: The teacher encouraged us to bring out our ideas on issues during lesson delivery

INB3: The teacher promoted student-to-student and teacher-to-student interactions

INB4: The lesson included a series of activities that share the common element of involving us in the lesson

INB5: The teacher employed strategies that motivated us to work together

INB6: The teacher used group work effectively during lesson delivery

\section{Interactivity: During the COVID-19}

IND1: The teacher gave adequate opportunity for us to involve and participate in the lesson

IND2: The teacher encouraged us to bring out our ideas on issues during lesson delivery

IND3: The teacher promoted student-to-student and teacher-to-student interactions

IND4: The lesson included a series of activities that share the common ele- 
ment of involving us in the lesson

IND5: The teacher employed strategies that motivated us to work together

IND6: The teacher used group work effectively during lesson delivery

\section{Assessment, Evaluation and Feedback: Before the COVID-19}

AEFB1: The teacher asked questions effectively

AEFB2: The teacher gave enough quizzes and assignments

AEFB3: The teacher graded and returned the quizzes and assignments promptly

AEFB4: The teacher clearly defined learning objectives for us to guide their learning

AEF5B: The teacher continued to assess our progress throughout the lesson

AEF6B: The teacher understood how we learned

AEFB7: The teacher provided a constructive feedback to us during the lesson

\section{Assessment, Evaluation and Feedback: During the COVID-19}

AEFD1: The teacher asked questions effectively

AEFD2: The teacher gave enough quizzes and assignments

AEFD3: The teacher graded and returned the quizzes and assignments promptly

AEFD4: The teacher clearly defined learning objectives for us to guide their learning

AEFD5: The teacher continued to assess our progress throughout the lesson

AEFD6: The teacher understood how we learned

AEFD7: The teacher provided a constructive feedback to us during the lesson 